\title{
Life cycle assessment of small-scale combined heat and power plant: environmental impacts of different forest biofuels and replacing district heat produced from natural gas
}

\author{
Jouni Havukainen ${ }^{\mathrm{a}, *}$, Mai Thanh Nguyen ${ }^{\mathrm{b}}$, Sanni Väisänen ${ }^{\mathrm{a}}$, Mika Horttanainen ${ }^{\text {a }}$ \\ ${ }^{a}$ Lappeenranta University of Technology, Sustainability Science. P.O. Box 20, FI-53851, \\ Lappeenranta, Finland \\ ${ }^{\mathrm{b}}$ Ton Duc Thang University, Faculty of Applied Sciences, Ho Chi Minh City, Vietnam
}

\begin{abstract}
Forest biomass is used in many countries as an abundant and easily accessible source of renewable energy. While forest biomass has certain advantages in terms of carbon sink capability, it cannot be considered an emission-free energy source, and the environmental differences among various forest biomass sources have been unclear. This study uses life cycle assessment for two purposes. The first is to quantify the environmental impacts of the energy production of a small-scale, combined heat and power production plant utilizing different forest biomasses. The second aim is to estimate the change in environmental impacts on district heat production from natural gas when partially replacing it by heat from the combined heat and power plant. The environmental impacts include global warming potential, acidification potential, and eutrophication potential. The calculated environmental impacts of utilizing different forest biofuels in the CHP plant in relation to produced energy are 2.2-5.1 $\mathrm{g}_{\mathrm{CO} 2, \text { eq. }} / \mathrm{MJ}_{\text {energy }}$ excluding biogenic carbon emission, 59-66 $\mathrm{g}_{\mathrm{CO} \text {,eq. }} / \mathrm{MJ}_{\text {energy }}$ with biogenic carbon emission, and 133-175 mgso2,eq./MJenergy and 18-22 mgPO34-,eq. $/ \mathrm{MJ}_{\text {energy }}$ with pellets, showing the highest values. The results indicate that by using forest biomass instead of natural gas in energy production, the global climate impacts are reduced when biogenic carbon is excluded, while the local effects are higher (acidification potential and eutrophication potential). Including biogenic carbon reduces the calculated climate benefit since the total emissions end up being 4-7\% over those of natural gas use. The potential benefits need to be weighed against the possible drawbacks.
\end{abstract}

Keywords: life cycle assessment, forest biomass, combined heat and power, environmental impacts, renewable energy

\section{Introduction}

Most of the current energy production methods cause adverse environmental impacts and often involve considerable resource uncertainties (Hammond, 2004). The (European Union, 2009) has targeted a $20 \%$ reduction in greenhouse gas (GHG) emissions by 2020 from the 1990 levels, and renewable energy production is deemed the key solution. So far, there has been widespread enthusiasm related to renewable energy generation; therefore, an environmental impact evaluation of a new bioenergy production process is obviously required.

Biomass is a renewable energy source with the highest potential to contribute to the energy needs of modern society worldwide (European Commission, 1997). Wood and other forms of biomass, including energy crops and industrial, agricultural (Cherubini and Ulgiati, 2010), and forestry

Havukainen, J., Nguyen, M.T., Väisänen, S., Horttanainen, M. 2018. Life cycle assessment of small-scale combined heat and power plant: environmental impacts of different forest biofuels and replacing district heat produced from natural gas. Journal of Cleaner Production 172C, 837-846. 
waste, are some of the main renewable energy resources available (Bridgewater, 2004). In Finland, the use of renewable sources for district heating has increased rapidly in recent years, and biofuels have contributed an important share in the total energy production to date (Salomón et al., 2011). With its abundant forest resources, Finland has the potential to develop renewable energy generation from forest biomass by utilizing combined heat and power (CHP) plants. Wood chip (WC) fuel chains have been examined, and improvements in the logistic chain have been sought (Tahvanainen and Anttila, 2011). The WCs have been produced from smalldiameter wood and wood residues. Additionally, industrial residues, such as cutter dust and sawdust, have been used to produce pellets for small-scale CHP plants.

To contribute to the mitigation of climate change, renewable energy technology has to produce less emission than the conventional fossil fuel-based energy production. Life cycle assessment (LCA) examines the potential environmental impacts throughout a product's life cycle, from raw material acquisition to final disposal (ISO 14040, 2006). LCA offers a powerful tool to analyze environmental impacts, including climate change effects of energy production methods. LCA has been conducted on photovoltaic systems (Sherwani and Usmani, 2010), biogas (Ishikawa et al., 2006), biomethane (Uusitalo et al., 2014), bioethanol production (Sandilands et al., 2009), and wind power production (Schleisner, 2000). Caserini et al. (2010) state that GHG savings can be obtained in comparison to conventional fuels if biomass supplying distance is less than $600 \mathrm{~km}$. Furthermore, Pehnt (Pehnt, 2008) found that most micro cogeneration systems are superior in GHG reduction potential compared to average electricity and heat supply as well as to state-ofart separate production. Kimming et al. (2011) concluded that utilizing agricultural biomass in small-scale CHP plants result to GHG emission reductions in comparison to fossil fuel-based systems. CHP can play an important role in the energy system. For example, CHP reduces fuel costs and contributes to the optimization of total energy costs, capacity, and societal costs (Østergaard, 2009).

Cherubini and Strømman (2011) state that in most LCA studies, replacing fossil energy with bioenergy results in a significant net reduction in GHG emissions. Eriksson et al. (2007) found that district heat and electricity production from biofuels would be environmentally sound strategy when comparing it to waste combustion and natural gas in Sweden. Similarly Kimming et al. (2011) concluded that small scale CHP production from agriculture biomass would be suitable in rural areas in Sweden and would reduce emissions considerably in comparison to fossil-fuel based system. According to a study by Caserini et al. (2010) net GHG emission savings are obtained when comparing biomass combustion to fossil fuel use when supplying distance is less than $600 \mathrm{~km}$ but the more locally affecting emission such particle matter, PAH and VOC are a negative environmental effect from the biomass combustion. The common practice of assuming the carbon neutrality of biomass use has also been challenged (Cherubini et al., 2016). While forest biomass has certain advantages in terms of carbon sink capability, it cannot be regarded as an emission-free energy source (Cherubini et al., 2016), and the environmental differences among various forest biomass sources are unclear.

LCA has been also used in calculating GHG emission impacts of biomass production chain (Jäppinen et al., 2014; Wihersaari, 2005) and use in energy production (Leino et al., 2016) in Finland. Jäppinen et al. (2014) concluded that harvesting residues and small diameter wood are most attractive sources for wood-based fuels.Leino et al. (2016) concluded that from climate change perspective, saw mills would benefit from using saw mill residues in CHP production.

Havukainen, J., Nguyen, M.T., Väisänen, S., Horttanainen, M. 2018. Life cycle assessment of small-scale combined heat and power plant: environmental impacts of different forest biofuels and replacing district heat produced from natural gas. Journal of Cleaner Production 172C, 837-846. 
Wihersaari (2005) found that reductions GHG emission reductions could be as much as $98 \%$. However, few studies have focused on other impact categories, such as acidification potential (AP) and eutrophication potential (EP) when biomass fuels replace fossil fuels. Distributed CHP production using wood-based fuels can help mitigate global GHG emissions by replacing fossil fuels. However, the impacts might be different when examining more locally affecting emissions that cause acidification and eutrophication. In addition, there is a research gap on the impact a small scale CHP plant utilizing wood-based fuels would have as a part of district heat production system. A small scale CHP plant could provide enough district heat during warmer months of the year when there is not enough heat load for large scale CHP plant and also provide renewable electricity.

Thus, this study's first goal is to quantify environmental impacts, including the global warming potential (GWP), the AP, and the EP of producing energy in a small-scale CHP plant that utilizes different forest biomasses. The second goal is to compare the environmental impacts of producing district heat solely from natural gas against producing part of the district heat in the CHP plant in the selected case area. The examined wood-based fuels include WCs from forest residues and small-diameter wood, as well as pellets from cutter dust and sawdust.

\section{Methods}

\subsection{Case study}

The technology examined in this study is a small-scale CHP plant using forest biomass, located in the Saimaanharju area in the municipality of Taipalsaari, Finland. The plant is used alongside the natural gas heating plant. The total heat demand in the Saimaanharju district heat grid averages $7000 \mathrm{MWh} / \mathrm{a}$ (Neuvonen, 2014). The small-scale CHP plant uses wood chips or pellets as fuels in a grate furnace. The combustion gases are directed to a heat exchanger where the heat is transferred to compressed air. The air is then used in a micro gas turbine to produce electricity. The aim of using pressurized air is to have reliable, error-free operations as much as possible. In addition to the electricity, the plant also produces heat which is directed to the district heating network and replaces the heat produced by natural gas (Karhunen and Koskelainen, 2013). A simplified process chart is presented in Figure 1. According to an updated simulation of the Saimaanharju CHP plant, it uses $580 \mathrm{~kW}$ (4 $400 \mathrm{MWh} / \mathrm{a}$ ) of fuel and produces $106 \mathrm{~kW}$ (approximately $790 \mathrm{MWh} / \mathrm{a}$ ) of electricity and $400 \mathrm{~kW}$ (approximately $3000 \mathrm{MWh} / \mathrm{a}$ ) of heat. The electric efficiency is $18 \%$, with a heat efficiency of $68 \%$ (Koskelainen, 2012). More information about the Saimaanharju CHP plant modeling has been reported (Sipilä et al., 2015), and the CHP plant has been compared with other distributed energy systems (Väisänen et al., 2016). More information about the Saimaanharju CHP plant in general (Sipilä et al.), Matlab modelling (Karjalainen, 2015) and comparison of the CHP plant with other distributed energy systems (Väisänen et al., 2016).

Havukainen, J., Nguyen, M.T., Väisänen, S., Horttanainen, M. 2018. Life cycle assessment of small-scale combined heat and power plant: environmental impacts of different forest biofuels and replacing district heat produced from natural gas. Journal of Cleaner Production 172C, 837-846. 


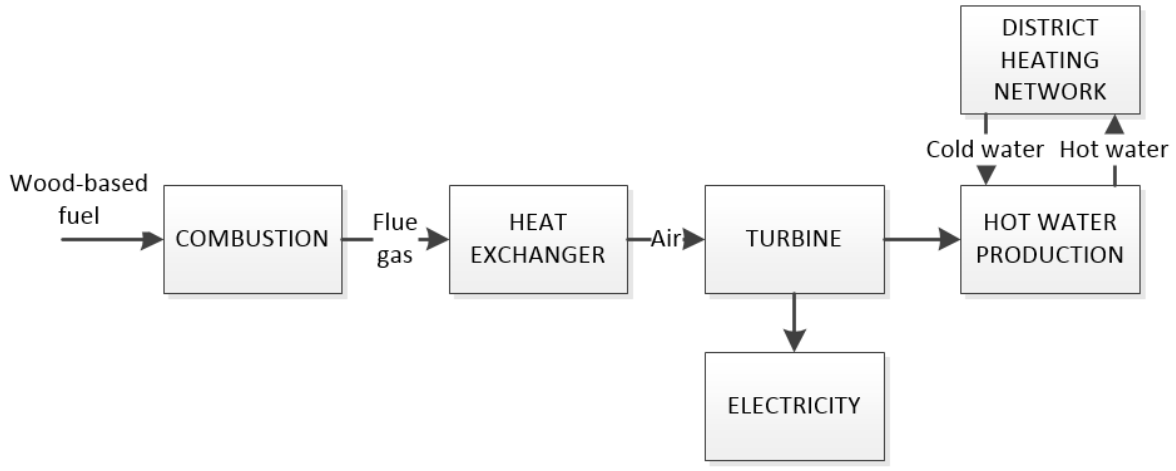

Figure 1. Simplified flow chart about small-scale CHP plant investigated in the study.

First, this study calculates and compares the environmental impacts of using wood-based fuels for the small-scale CHP plant. Second, the environmental impacts of producing district heat solely from natural gas are compared against partially producing heat from the small-scale CHP plant in the Saimaanharju area. The system boundaries for calculating the emissions of energy production in the CHP plant and the changes in the environmental impacts of the Saimaanharju district's heat production are represented in Figure 2.

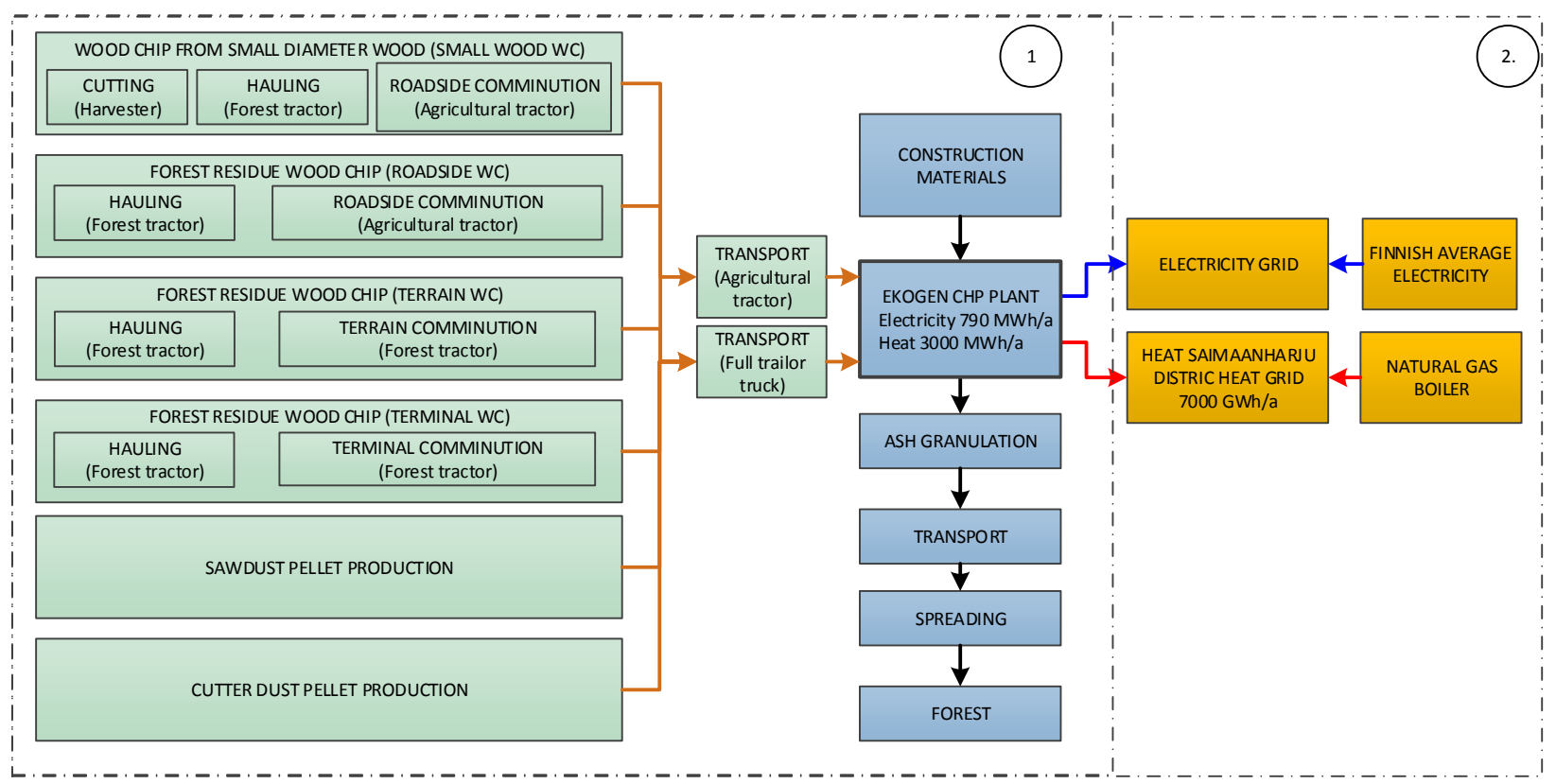

Figure 2. System boundaries and reference flows for calculating the environmental impacts of producing energy with a small-scale CHP plant utilizing different wood-based fuels (System boundary 1) and for determining the environmental impacts in Saimaanharju when district heat produced from natural gas is partially replaced by heat from the small-scale CHP plant (System boundary 2).

Havukainen, J., Nguyen, M.T., Väisänen, S., Horttanainen, M. 2018. Life cycle assessment of small-scale combined heat and power plant: environmental impacts of different forest biofuels and replacing district heat produced from natural gas. Journal of Cleaner Production 172C, 837-846. 


\subsection{Life cycle assessment}

LCA was performed in accordance with ISO standards 14040 and 14044 (ISO 14040, 2006; ISO 14044, 2006). The functional unit was $1 \mathrm{MJ}$ of produced energy (21\% electricity and $79 \%$ heat); Figure 2 shows the two system boundaries, as well as the reference flows. The impact assessment was performed by using GaBi 6.0 software (Thinkstep, 2015) with the CML2001April 2013 life cycle impact assessment methodology (CML - Department of Industrial Ecology, 2016; Guinée et al., 2002). The environmental impact categories included GWP (gCO2, equivalent),

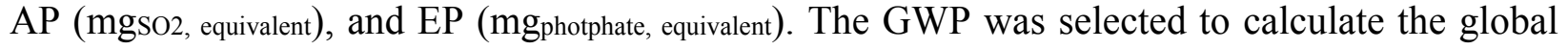
environmental impact of utilizing wood based fuels in CHP production and estimate the impact when replacing fossil fuels. Also the biomass carbon effect on GWP is calculated. Since small scale CHP plant is part of distributed local energy production, also AP and EP impact categories were included to study the local environmental impacts that energy production from wood based fuels could have. The impact assessment was done until the characterization phase. The results of the environmental impact assessment of district heat production were normalized to compare the relative changes of the investigated impact categories - GWP, EP, and AP. Normalization includes calculation of the magnitude of the category results relative to reference information." The normalization of the results was conducted by using CML2001-April 2013 EU25+3 values (CML - Department of Industrial Ecology, 2016; Guinée et al., 2002), which means that the reference information was the total emissions of a given category produced in EU 28 countries. The study focused on comparing the environmental impacts of using different wood-based fuels in the small CHP plant and estimating the changes in environmental impacts if this small-scale CHP plant would be used to partially replace district heat produced from natural gas. The consequential impacts of diverting the studied wood-based fuels or building materials from other possible uses are beyond the scope of this study, as well as deciding whether to use the smallscale CHP plant for utilizing biomass or other energy production methods.

The emissions from land use change (LUC) were not included since the small diameter wood and forest residues are assumed to come from thinning of existing forest without land use change. The saw dust and cutter dust on the other hand are residuals from wood industry and as wastes considered to have zero emission burden for following processes. The environmental impact caused by manufacturing and maintaining of capital goods related to obtaining forest fuel were excluded due to earlier findings on low effect on environmental impact results when studying seedling production (Cambria and Pierangeli, 2011), pulpwood supply chain (GonzálezGarcía et al., 2009) or forest biomass to biofuel production (Zhang et al., 2015). The carbon sequestration and release effect were included by taking into account the temporal asymmetry between biomass combustion and regrowth. The used GWP factor for forest biomass-originated carbon (biogenic carbon) was $0.45 \pm 0.05 \mathrm{kgCO}$,eq. $/ \mathrm{kg} \mathrm{CO} 2$ biogenic (Cherubini et al., 2016). LCA studies usually assume that forest biomass is carbon neutral; therefore, this study's results both include and exclude the biogenic carbon emissions.

Havukainen, J., Nguyen, M.T., Väisänen, S., Horttanainen, M. 2018. Life cycle assessment of small-scale combined heat and power plant: environmental impacts of different forest biofuels and replacing district heat produced from natural gas. Journal of Cleaner Production 172C, 837-846. 


\subsection{Life cycle inventory}

\subsubsection{Wood chip production}

The feedstocks for WC products include small-diameter wood and forest residues. The information for a small-diameter WC production chain was obtained from a local supplier in the Taipalsaari municipality (Brofeldt, 2013). The forest residue WC chains differ from each other by the comminution site. In the terrain comminution chain the comminution is done in the forest by the same machine that collects the forest residue and no haulage of the forest residue is needed. In the road side comminution chain the food residues are hauled next to the forest road where a comminution of the forest residue takes place so that wood chips are loaded to a transport vehicle. In the terminal comminution chain the forest residues are transported to centralized terminal where the comminution takes place and the wood chips are transported from there to the customer. The forest residue WC chains in this study were based on average chains in Finland, according to Wihersaari and Palosuo (2000). Table 1 presents the diesel consumption of WC production chains. More specific information on the forest residue production chain in Finland can be found from Wihersaari and Palosuo (2000) and Wihersaari (2005).

Table 1. Diesel consumption in producing small-diameter wood and forest residue WCs and properties of these fuels (Asikainen et al., 2012; Brofeldt, 2013; Heikkilä et al., 2005; Karttunen et al., 2010; Laitila et al., 2010; Lectura, 2013; Wihersaari and Palosuo, 2000).

\begin{tabular}{lccccc}
\hline \multicolumn{1}{c}{ Wood material } & Small-diameter wood & \multicolumn{2}{c}{ Forest residue } & & Unit \\
\hline \multicolumn{1}{c}{ Comminution site } & Roadside & Terrain & Roadside & Terminal & \\
\hline Cutting & 0.00260 & & & & $1 \mathrm{diesel} / \mathrm{kg}$ \\
Haulage & 0.00101 & & 0.083 & 0.0056 & $1 \mathrm{diesel} / \mathrm{kg}$ \\
Comminution & 0.00101 & $0.178^{1}$ & 0.135 & 0.00267 & $1 \mathrm{diesel} / \mathrm{kg}$ \\
Transportation & 0.00101 & 0.0438 & 0.044 & 0.00111 & $1 \mathrm{diesel} / \mathrm{kg}$ \\
\hline Total & 0.0056 & 0.22 & 0.26 & 0.00937 & $1 \mathrm{diesel} / \mathrm{kg}$ \\
\hline Moisture & 36 & 40 & 40 & 40 & $\%$ \\
Heating value LHV & 11.6 & 10.7 & 10.7 & 10.7 & $\mathrm{MJ} / \mathrm{kg}$ \\
\hline
\end{tabular}

${ }^{1}$ Includes hauling

The emissions of the harvester, agricultural tractor, forest tractor, and full trailer truck were obtained from the (Lipasto, 2012) database. The transport was assumed to use the Euro 5th-class full trailer truck, and the emissions from diesel use also came from the (Lipasto, 2012) database. Table 2 presents the emissions from working machines and transport vehicles. The emissions caused by manufacturing the required equipment were excluded due to the lack of available data and information on how much of the emissions could be allocated for the pellets used in this particular plant.

Havukainen, J., Nguyen, M.T., Väisänen, S., Horttanainen, M. 2018. Life cycle assessment of small-scale combined heat and power plant: environmental impacts of different forest biofuels and replacing district heat produced from natural gas. Journal of Cleaner Production 172C, 837-846. 
Table 2. Working machine and transport vehicle emissions when using diesel (Lipasto, 2012).

\begin{tabular}{lccccc}
\hline Emission & $\begin{array}{c}\text { Harvester } \\
\mathrm{g} / 1 \text { diesel }\end{array}$ & $\begin{array}{c}\text { Forest } \\
\text { tractor } \\
\mathrm{g} / 1 \text { diesel }\end{array}$ & $\begin{array}{c}\text { Agricultural } \\
\text { tractor } \\
\mathrm{g} / 1 \text { diesel }\end{array}$ & $\begin{array}{c}\text { Full trailer } \\
\text { truck } \\
\mathrm{g} / 1 \text { diesel }\end{array}$ & $\begin{array}{c}\text { Heavy delivery } \\
\text { truck } \\
\mathrm{g} / 1 \text { diesel }\end{array}$ \\
\hline $\mathrm{CO}$ & 5.4 & 5.2 & 8.3 & 0.4 & 0.16 \\
$\mathrm{HC}$ & 1 & 1.1 & 2.8 & 0.05 & 0.02 \\
$\mathrm{NO}$ & 11 & 12 & 22 & 8.5 & 3.40 \\
$\mathrm{PM}$ & 0.27 & 0.43 & 1.2 & 0.09 & 0.04 \\
$\mathrm{CH}$ & 0.15 & 0.15 & 0.15 & 0.005 & 0.08 \\
$\mathrm{~N}_{2} \mathrm{O}$ & 0.071 & 0.07 & 0.072 & 0.07 & 0.08 \\
$\mathrm{NH}_{3}$ & & & & 0.01 & 0.012 \\
$\mathrm{SO}_{2}$ & 0.017 & 0.017 & 0.017 & 0.02 & 0.008 \\
$\mathrm{CO}_{2}$ & 2607 & 2607 & 2624 & 2491 & 1197 \\
\hline
\end{tabular}

\subsubsection{Pellet production}

The pellets were assumed to be produced from either sawdust or cutter dust. Sawdust pellets require heat in the production process since the raw material is wet and has to be dried, whereas cutter dust is already dry enough for pellet production. Additionally, electricity is needed in the pellet production process (Hagberg et al., 2009). The pellet fuel is transported at an average distance of $108 \mathrm{~km}$ (Statistics Finland, 2012). Full trailer trucks were assumed to be used for the transportation of pellets. Table 3 shows the energy needs in pellet production and transport, as well as the pellet properties.

Table 3. Electricity and heat consumption in sawdust and cutter dust pellet production and pellet properties (Alakangas, 2000; Hagberg et al., 2009; Statistics Finland, 2012).

\begin{tabular}{|c|c|c|c|}
\hline Raw material & Sawdust & Cutter dust & Unit \\
\hline Electricity use & 0.04 & 0.02 & $\mathrm{MJ} / \mathrm{MJ}$ fuel \\
\hline Heat use & 0.2 & & $\mathrm{MJ} / \mathrm{MJ}$ fuel \\
\hline Transport & 0.00222 & & 1 diesel $/ \mathrm{kg}$ \\
\hline Moisture & 10 & 10 & $\%$ \\
\hline Heating value $L H V_{a r}$ & 17 & 17 & $\mathrm{MJ} / \mathrm{kg}$ \\
\hline
\end{tabular}

\subsubsection{Construction materials for Saimaanharju CHP plant}

The emissions from producing the construction materials for the Ekogen plant were included into the LCA, but the energy consumption of construction phase was not recorded and it was excluded from the LCA. The lifetime of the plant was assumed to be 20 years, and the yearly emissions were divided evenly by that period. Table 4 presents the construction materials for the plant and the emissions from producing them. 
Table 4. Saimaanharju CHP plant construction materials and masses (Ecoinvent Centre, 2010; Juhl, 2013; Koskelainen, 2012; Paroc Group, 2013; Thinkstep, 2015).

\begin{tabular}{llrrr}
\hline Material & $\begin{array}{l}\text { Mass } \\
\mathrm{kg}\end{array}$ & \multicolumn{1}{l}{$\begin{array}{l}\mathrm{GWP} \\
\mathrm{kgCO2,eq} / \mathrm{kg}\end{array}$} & $\begin{array}{l}\text { Acidification } \\
\mathrm{kgSO2,eq} / \mathrm{kg}\end{array}$ & \multicolumn{1}{l}{$\begin{array}{l}\text { Eutrophication } \\
\mathrm{kgPO34-eq} / \mathrm{kg}\end{array}$} \\
\hline Steel & 20098 & 2.35 & 0.0068 & 0.00048 \\
Furnace & 12490 & 1.26 & 0.036 & 0.0011 \\
Reinforced concrete & 15000 & 0.55 & 0.00079 & 0.000087 \\
\hline Total & 47588 & & & \\
\hline
\end{tabular}

\subsubsection{Combustion}

The $\mathrm{NO}_{2}, \mathrm{CH}_{4}$, and $\mathrm{SO}_{2}$ emissions from combusting WCs and pellets are estimated to be 0.114 $\mathrm{g} / \mathrm{MJ}$ fuel, $0.0008 \mathrm{~g} / \mathrm{MJ}$ fuel, and $0.044 \mathrm{~g} / \mathrm{MJ}$ fuel (Alakangas, 2000; Koskelainen, 2012; Raiko et al., 2002; Vesterinen et al., 1985; Wihersaari and Palosuo, 2000). Nitrous oxide $\left(\mathrm{N}_{2} \mathrm{O}\right)$ is easily disintegrated at high temperatures of over $930^{\circ} \mathrm{C}$ (Wihersaari and Palosuo, 2000). According to Winter et al. (1999), the concentration of H-radicals in combusting hydrogen-rich biofuels, low nitrogen contents, and relatively high $\mathrm{NH}_{3}$ levels explain the very low $\mathrm{N}_{2} \mathrm{O}$ emissions from biomass combustion. Since the temperature in the furnace of the Saimaanharju CHP plant is higher than $1000^{\circ} \mathrm{C}$ (Koskelainen, 2012), the $\mathrm{N}_{2} \mathrm{O}$ emissions are assumed to be negligible.

\subsubsection{Ash granulation, transport, and spreading}

Ash from combustion is assumed to be granulated by using electricity, transported with full trailer trucks, and spread into the forest with a forest tractor (Wihersaari and Palosuo, 2000). Values from the Lipasto (2012) database for the Euro 5th-class full trailer truck were used for vehicle emissions. The energy requirement of ash granulation is $0.0153 \mathrm{MJ}$ electricity $/ \mathrm{kg}$, and those for transport and spreading are $0.002351 \mathrm{diesel} / \mathrm{kg}$ and $0.0051 \mathrm{diesel} / \mathrm{kg}$ (Wihersaari and Palosuo, 2000).

\subsubsection{Energy production and use}

The emission factors for electricity were determined by using the Finnish production mix plan from Gabi 6 and by applying the average electricity production mix in Finland between June 2006 and September 2013 (Table 5). The sawdust pellet process required renewable heat from solid biofuel, and the emissions were obtained from Gabi 6. The values of the emissions from producing heat from natural gas and obtaining diesel also came from Gabi 6. The used $\mathrm{NO}_{2}$, $\mathrm{CH}_{4}$, and $\mathrm{SO}_{2}$ emission factors for the heat produced from natural gas were $0.72 \mathrm{~g} / \mathrm{MJ}, 0.055$ $\mathrm{g} / \mathrm{MJ}$, and $0.0093 \mathrm{~g} / \mathrm{MJ}$ (Thinkstep, 2015).

Havukainen, J., Nguyen, M.T., Väisänen, S., Horttanainen, M. 2018. Life cycle assessment of small-scale combined heat and power plant: environmental impacts of different forest biofuels and replacing district heat produced from natural gas. Journal of Cleaner Production 172C, 837-846. 
Table 5. Average electricity production mix in Finland, June 2006-September 2013 (Soimakallio, 2013).

\begin{tabular}{lc}
\hline Source of electricity & Share (\%) \\
\hline Nuclear power & 30 \\
Hydropower & 19 \\
Coal & 15 \\
Wood and other biofuels & 14 \\
Natural gas & 13 \\
Peat & 7 \\
Other domestic fuels, not biofuels & 1 \\
Oil & 0.5 \\
Wind power & 0.5 \\
\hline Total & 100 \\
\hline
\end{tabular}

\subsubsection{Uncertainty analysis}

The values collected for the life cycle inventory data often include the selection of values for calculation from a set of available values. Uncertainty analysis was conducted for the calculation of the Saimaanharju CHP plant's environmental impacts to increase the robustness of the LCA results and to find out how much the environmental impacts would vary according to the changes made in the initial data.

The energy efficiency of production processes is improving continuously, and it is also possible to reduce the energy use of the wood-based fuel production chains. Therefore, the impact of decreased energy use in the production chains of WCs and pellets was estimated in the uncertainty analysis. The values used in the uncertainty analysis for WC production are summarized in Table 6, and those for pellet production are listed in Table 7.

The $\mathrm{NO}_{2}, \mathrm{CH}_{4}$, and $\mathrm{SO}_{2}$ emissions from combusting WCs and pellets also varied at $0.08-0.149$ $\mathrm{g} / \mathrm{MJ}$ of fuel, $0.00056-0.00104 \mathrm{~g} / \mathrm{MJ}$ of fuel, and $0.034-0.063 \mathrm{~g} / \mathrm{MJ}$ of fuel (Alakangas, 2000; Koskelainen, 2012; Raiko et al., 2002; Vesterinen et al., 1985; Wihersaari and Palosuo, 2000). Additionally, the heating values of wood-based fuels changed somewhat, depending on the moisture content of the produced fuels, which also affected the results of the LCA. The LHV ar of the pellets varied between $14 \mathrm{MJ} / \mathrm{kg}$ and $18 \mathrm{MJ} / \mathrm{kg}$ (Alakangas, 2000), the LHV ar of the WCs from small-diameter wood ranged from $9.6 \mathrm{MJ} / \mathrm{kg}$ to $13 \mathrm{MJ} / \mathrm{kg}$, and the $\mathrm{LHV}_{\text {ar }}$ of the WCs from forest residues ranged from $8 \mathrm{MJ} / \mathrm{kg}$ to $11 \mathrm{MJ} / \mathrm{kg}$.

Table 6. Values used in uncertainty analysis for energy consumption in WC production (Asikainen et al., 2012; Karjalainen and Asikainen, 1996; Kärhä et al., 2011).

\begin{tabular}{lccccc}
\hline Wood material & Small-diameter wood & Forest residue & & Unit \\
\hline Comminution site & Roadside & Terrain & Roadside & Terminal & \\
\hline Cutting & 0.0017 & & & & 1 diesel $/ \mathrm{kg}$ \\
Haulage & 0.00079 & & 0.0008 & 0.0041 & 1 diesel $/ \mathrm{kg}$ \\
Comminution & 0.00068 & 0.0022 & 0.0014 & 0.0014 & 1 diesel $/ \mathrm{kg}$ \\
\hline
\end{tabular}

Havukainen, J., Nguyen, M.T., Väisänen, S., Horttanainen, M. 2018. Life cycle assessment of small-scale combined heat and power plant: environmental impacts of different forest biofuels and replacing district heat produced from natural gas. Journal of Cleaner Production 172C, 837-846. 
Table 7. Values used in uncertainty analysis for energy consumption in pellet production (Chen, 2009; Hagberg et al., 2009).

\begin{tabular}{lccc}
\hline Raw material & Sawdust & Cutter dust & Unit \\
\hline Electricity use & 0.02 & 0.01 & $\mathrm{MJ} / \mathrm{MJ}$ fuel \\
Heat use & 0.14 & & $\mathrm{MJ} / \mathrm{MJ}$ fuel \\
\hline
\end{tabular}

\section{Results}

\subsection{Environmental impacts of energy produced in small-scale CHP plant}

The Saimaanharju CHP plant emissions causing global warming, eutrophication, and acidification were calculated when using $4400 \mathrm{MWh} / \mathrm{a}$ of wood-based fuel and producing 790 $\mathrm{MWh} / \mathrm{a}$ of electricity and $3000 \mathrm{MWh} / \mathrm{a}$ of heat.

\subsubsection{Global warming potential}

Figure 3 illustrates the GWP results, including and excluding the biogenic carbon emissions from the Saimaanharju CHP plant. The biogenic carbon emissions cause the majority of the emissions, 11-30 times more than other emission categories combined, contributing 57-64 gc02,eq./MJ of energy. Excluding the biogenic carbon emissions, obtaining fuels (including the related transport, heat, electricity, comminution, hauling, and cutting) causes the most significant portion of the emissions (82-92\%), while plant materials contribute about 6-13\% of the emissions. In WC production from small-diameter wood, cutting down trees produces most of the emissions (41 $\%$ ), and there are no significant differences in emission values among hauling, comminution, and transport (14\% for each contributor). Producing WCs from forest residues (including terrain, terminal, and roadside WCs) does not require cutting down trees; therefore, emissions mainly come from hauling, comminution, and transport. Hauling terminal WCs results in the highest emissions (1.8 $\mathrm{gCO}_{\mathrm{CO}, \mathrm{eq}} / \mathrm{MJ}$ of energy), followed by roadside WCs $(0.8$ gco2,eq./MJ of energy),

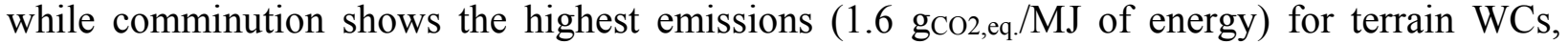

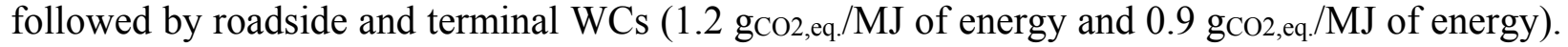
Transport contributes $8-17 \%$ of the emissions in WC production from forest residues and pellet production. In WC production, electricity consumption produces most of the emissions (70-72 $\%$ ), whereas in saw dust pellet production, consumed heat accounts for $14 \%$ of the emissions. The emission amounts from other contributors are low or negligible.

Havukainen, J., Nguyen, M.T., Väisänen, S., Horttanainen, M. 2018. Life cycle assessment of small-scale combined heat and power plant: environmental impacts of different forest biofuels and replacing district heat produced from natural gas. Journal of Cleaner Production 172C, 837-846. 


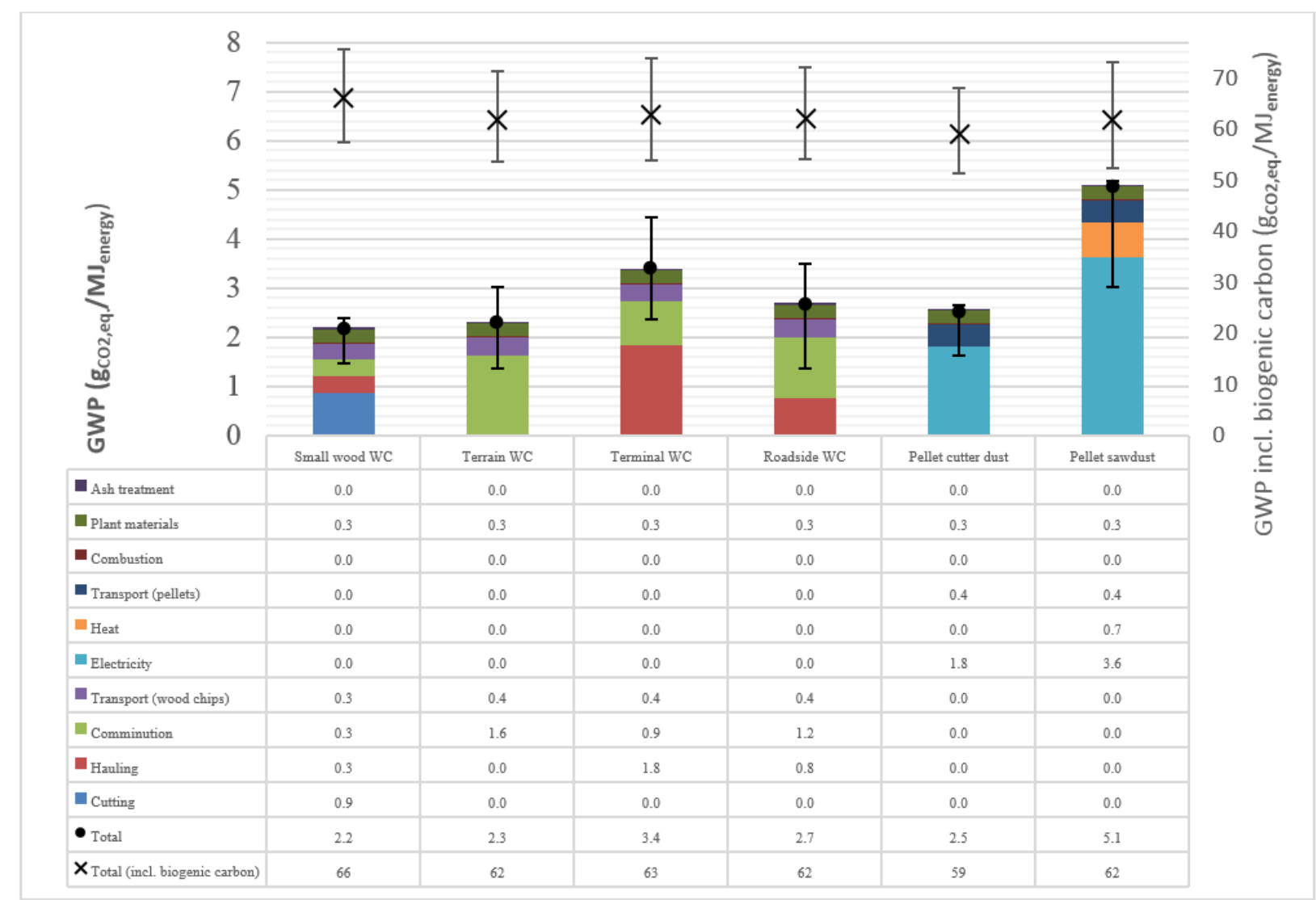

Figure 3. Saimaanharju CHP plant's GHG emissions in relation to functional unit (1 MJ of produced energy), calculated based on System boundary 1, including the uncertainty of the results (represented by the error bar).

\subsubsection{Acidification potential}

Combustion is responsible for the main percentage of the emissions causing the AP (72-94\%), as shown in Figure 4. The highest combustion emissions result from using WCs from smalldiameter wood (133 mgso2,eq./MJ of energy), and the lowest emissions come from cutter dust and sawdust pellets (125 mgso2,eq/MJ of energy). There are no significant differences among the combustion emission values of WCs produced from wood residues (128 mgso2,eq./MJ of energy). Heat consumption accounts for $21 \%$ of the emissions in the production process of sawdust pellets due to the wet raw material which needs to be dried, while consumed electricity produces low emissions (4-5\%) in the production processes of both cutter dust and sawdust pellets.

Havukainen, J., Nguyen, M.T., Väisänen, S., Horttanainen, M. 2018. Life cycle assessment of small-scale combined heat and power plant: environmental impacts of different forest biofuels and replacing district heat produced from natural gas. Journal of Cleaner Production 172C, 837-846. 


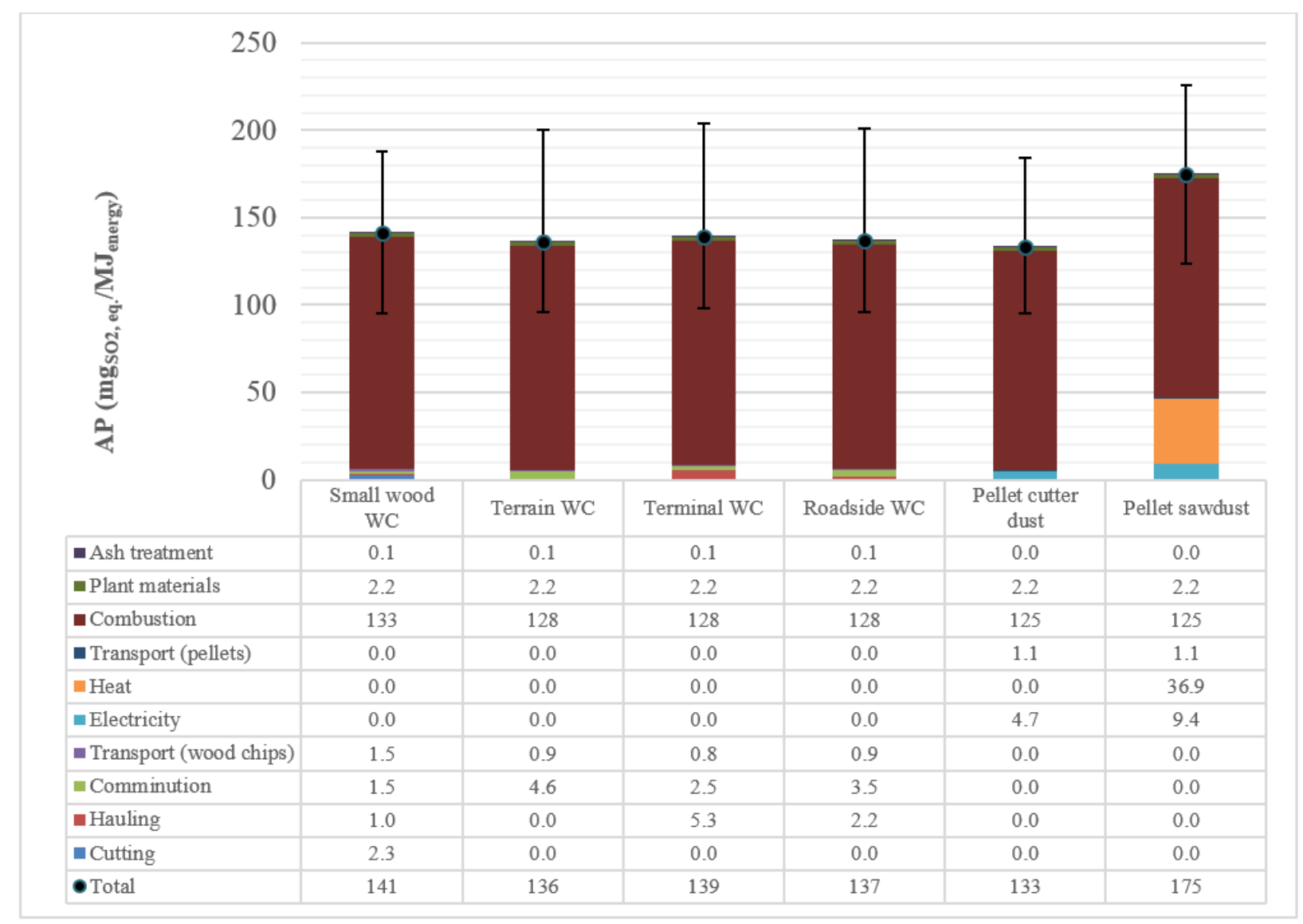

Figure 4. Saimaanharju CHP plant emissions causing AP in relation to functional unit (1 MJ of produced energy), calculated based on System boundary 1, including the uncertainty of the results (represented by the error bar).

\subsubsection{Eutrophication potential}

Eutrophication results from airborne emissions containing nitrogen. The findings show that combustion comprises the largest segment of emissions causing the EP (77-95\%) (Figure 4). Obtaining fuel (including the related transport, heat, electricity, comminution, hauling, and cutting) contributes a small fraction of the emissions, and with the exception of sawdust pellet production, heat consumption contributes about $17 \%$ of the emissions causing the EP. 


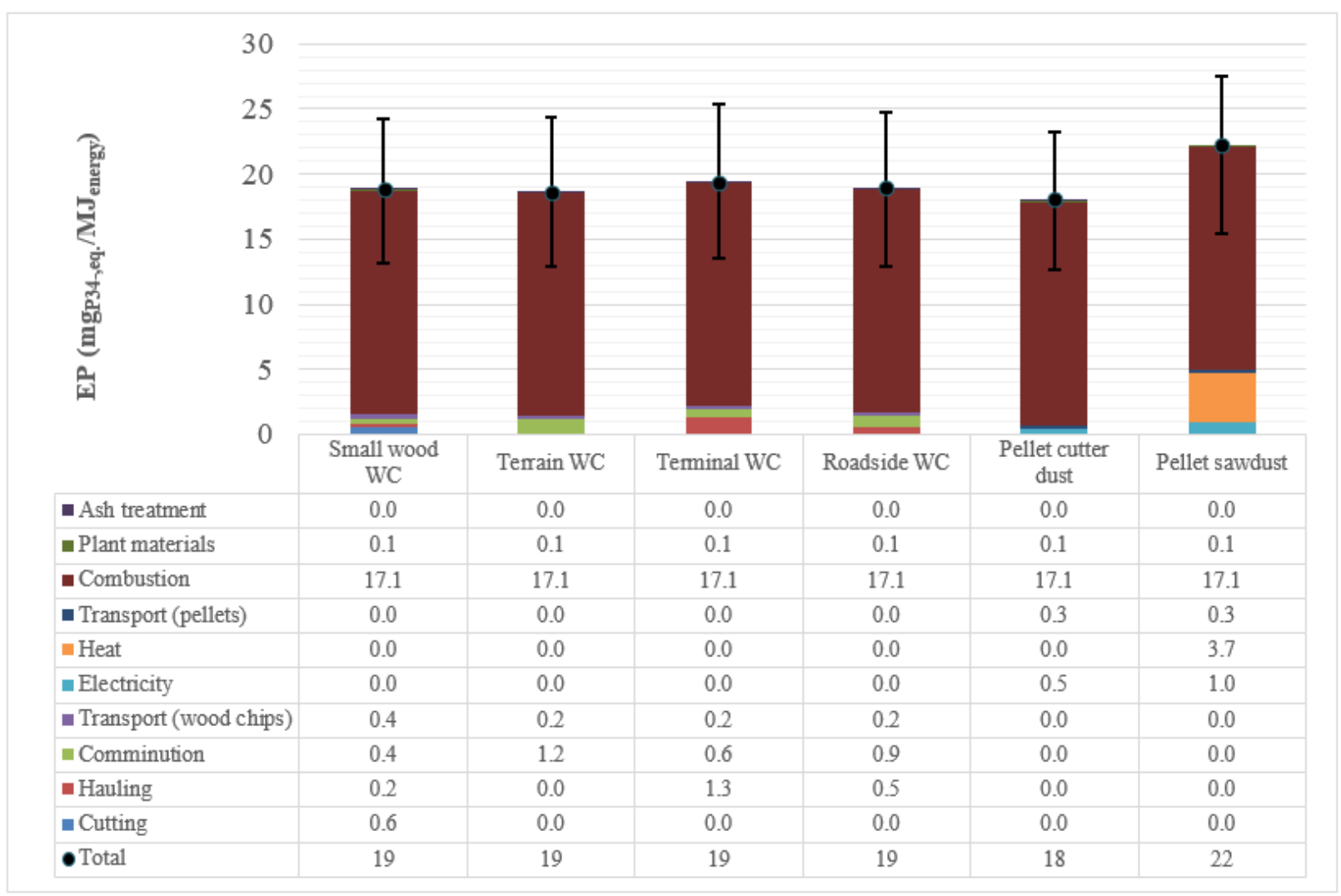

Figure 5. Saimaanharju CHP plant emissions causing EP in relation to functional unit (1 MJ of produced energy), calculated based on System boundary 1, including the uncertainty of the results (represented by the error bar).

\subsection{Environmental impacts of district heat production in the Saimaanharju area}

The Saimaanharju area needs approximately $7000 \mathrm{MWh} / \mathrm{a}$ of heat annually for district heating purposes. The situation where all this heat is produced with a natural gas boiler is compared to the case where the Saimaanharju CHP plant produces part of it (3000 MWh/a), and the rest is produced with a natural gas boiler. The Saimaanharju CHP plant also produces electricity (790 $\mathrm{MWh} / \mathrm{a}$ ), and taking into account the emission reductions from displacing the average grid electricity reduces the overall emissions.

\subsubsection{Emissions in relation to produced heat}

Figure 6 shows the emissions in relation to the produced heat (7 $000 \mathrm{MWh} / \mathrm{a})$. Compared to the heat produced only from natural gas, producing part of the heat from biomass results in lower GHG emissions in relation to the heat produced, when excluding biogenic carbon emissions. On the other hand, including biogenic carbon emissions leads to 2-7\% higher GHG emissions than those of natural gas use. Emissions related to eutrophication and acidification are increasing. The heat production emission factors of natural gas in relation to the heat produced are 72 $\mathrm{gCO}_{\text {,eq. }} / \mathrm{MJ}_{\text {heat }}, 55 \mathrm{mgsO}$,eq. $/ \mathrm{MJ}_{\text {heat, }}$ and $9 \mathrm{mgpO34- \text {eq. }} / \mathrm{MJ}_{\text {heat, }}$ while the emission factors in woodbased fuel utilization are 33-35 gCO2,eq./MJ $\mathrm{Meat}_{\text {, }}$ 80-103 $\mathrm{mgsO}_{\text {,eq. }} / \mathrm{MJ}_{\text {heat, }}$ and 12-13 $\mathrm{mgPO} 4-$ ,eq. $/ \mathrm{MJ}_{\text {heat }}$ when accounting for electricity displacement and excluding biogenic carbon emissions. Havukainen, J., Nguyen, M.T., Väisänen, S., Horttanainen, M. 2018. Life cycle assessment of small-scale combined heat and power plant: environmental impacts of different forest biofuels and replacing district heat produced from natural gas. Journal of Cleaner Production 172C, 837-846. 
The GWP of natural gas is the most dominant. Acidification is highest in sawdust pellets, followed by the rest of the wood-based fuels, and lowest in natural gas. There are no significant differences in eutrophication among wood-based fuels. If the electricity displacement is not considered, the emission factors would increase to $19-21 \%$ in GHG emissions, $18-22 \%$ in acidification, and $13-29 \%$ in eutrophication.

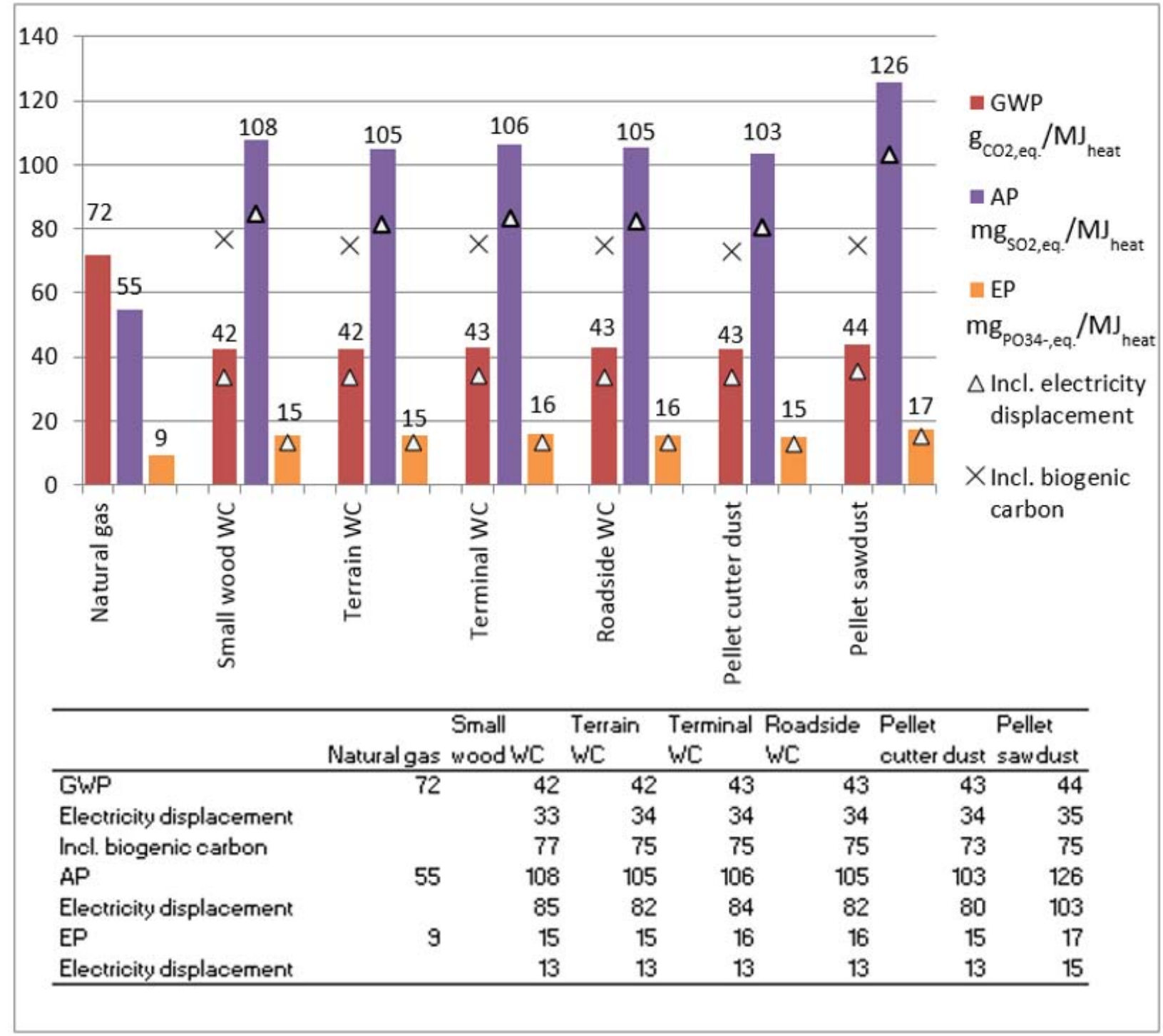

Figure 6. Emissions causing global warming, including and excluding biogenic carbon

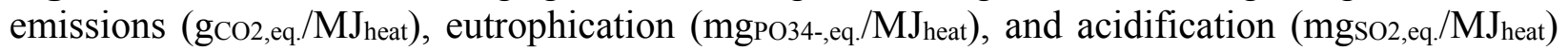
when producing heat for the Saimaanharju area from natural gas only compared to $43 \%$ of heat produced from different biofuels in the Saimaanharju CHP plant and the rest from natural gas.

\subsubsection{Normalization}

Figure 7 summarizes the normalized results of the annual environmental impacts of the Saimaanharju district's heat production.

Havukainen, J., Nguyen, M.T., Väisänen, S., Horttanainen, M. 2018. Life cycle assessment of small-scale combined heat and power plant: environmental impacts of different forest biofuels and replacing district heat produced from natural gas. Journal of Cleaner Production 172C, 837-846. 


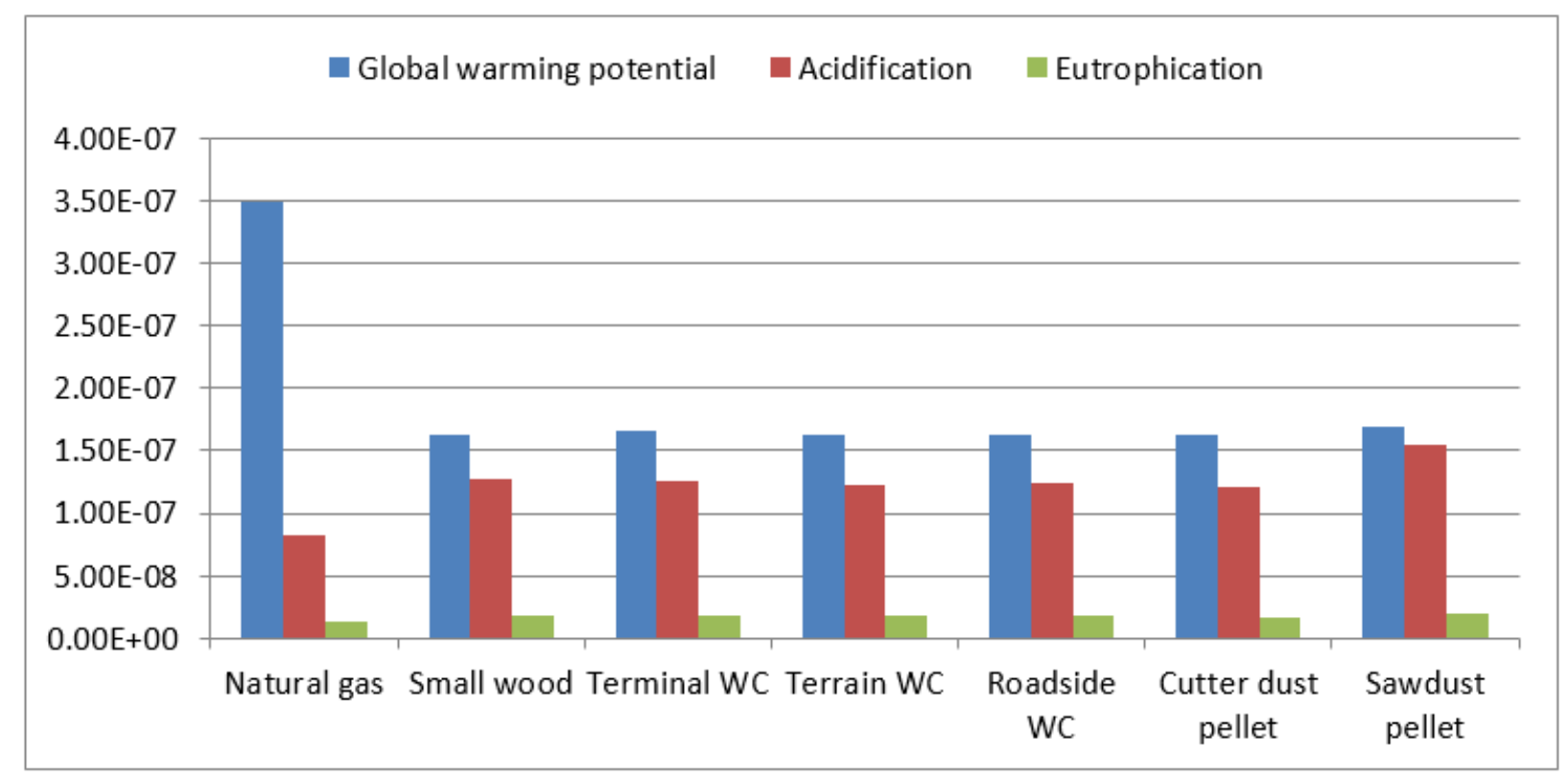

Figure 7. Normalized values (EU-25+3) of annual emissions of the Saimaanharju district's heat plant, causing global warming, acidification, and eutrophication with natural gas only and with different biofuel and natural gas combinations.

The change in relation to the yearly emissions of the EU-25+3 is more significant in GHG emissions than in acidification and eutrophication. Natural gas emissions have the lowest acidification impact, but the difference from wood-based fuels is small. All of the examined fuels have relatively low eutrophication impacts. The results show that the reduction in GHG emissions is more significant than the increase in emissions causing acidification and eutrophication.

\section{Discussion}

From the GHG emission perspective, obtaining fuel for CHP production causes the most significant percentage of the emissions (approximately $90 \%$ ); therefore, it is worthwhile to examine the causes of emissions in fuel-obtaining chains. These emissions are caused by the diesel used in working machines in the case of WCs, as well as heat and electricity consumption in pellet production. According to Arvidsson et al. (2012), the amount of fossil energy used during the production of biofuels is an important factor in the optimization of production systems. Supply chains of forest residues for combustion in the Saimaanharju CHP plant are responsible for emissions in the production phase. The GHG emission results related to obtaining forest fuels are in line with those of previous studies. This study notes $2-4$ gCO2,eq. $/ \mathrm{MJ}$ for forest fuels, while Berg and Lindholm (2005) estimate that harvest logging residues in Central Sweden

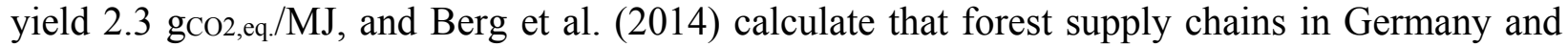
Sweden have a GHG emission range of 1-2.8 gCO2,eq. MJ. In this study, transport contributes 12$17 \%$ of the emissions causing the GWP in WC production from forest residues.

According to Wihersaari (2005), the emissions from collecting, chipping, and transporting residues depend on harvesting and chipping methods and transportation distance. Valante et al.

Havukainen, J., Nguyen, M.T., Väisänen, S., Horttanainen, M. 2018. Life cycle assessment of small-scale combined heat and power plant: environmental impacts of different forest biofuels and replacing district heat produced from natural gas. Journal of Cleaner Production 172C, 837-846. 
(2011) also report that transportation accounts for $31 \%$ of emissions, while Puettmann and Lippke (2013) reveal that the transportation and collection of wood waste feedstocks contribute minimally $(8 \%)$ to the GWP. The process of WC production from small-diameter wood generates lower GHG emissions per produced energy $(2.2$ gCO2,eq./MJ) compared to the production of other wood fuels, with sawdust pellets yielding the most $\left(5.1 \mathrm{gCO}_{\text {,eq }} / \mathrm{MJ}\right)$. In contrast, the production of pellets has a higher impact due to its required amount of electricity and heat compared to WC pathways. Thus, research into more efficient methods of wood pellet production would help diminish its environmental impacts.

The combustion of forest biomass is often assumed to be carbon neutral. However, the temporal asymmetry between biomass combustion and regrowth has an impact on the GWP of forest biomass use (Cherubini et al., 2016). As the results show, taking this biogenic carbon emission into consideration would significantly increase the GWP of forest biomass. The small-diameter wood comes from the thinning of the industrial forests, and the removal of this biomass aims at increasing the growth of the remaining trees. This might result in higher carbon sequestration of the remaining trees, but its extent is unclear, and this issue is not included in this study.

Combustion is responsible for the main percentage of emissions causing acidification (72-94\%). The combustion emissions consist of $\mathrm{SO}_{2}$ and $\mathrm{NO}_{2}$, each amounting to half of the total $\mathrm{SO}_{2}$,eq. emissions. The $\mathrm{SO}_{2}$ emissions arise from the fuel's sulfur content (assumed to be $0.04 \%$ for wood), resulting in $\mathrm{SO}_{2}$ emissions of 43-48 mgSO2/MJ (Alakangas, 2000; Raiko et al., 2002). The $\mathrm{NO}_{\mathrm{x}}$ emissions are assumed to be $114 \mathrm{mgNO} / \mathrm{MJ}$ (Vesterinen et al., 1985; Wihersaari and Palosuo, 2000). Similar to acidification, combustion emissions from $\mathrm{NO}_{\mathrm{x}}$ also constitute the main reason for eutrophication (77-95\%). In this study, acidification occurs at a higher level than eutrophication from all resources, based on the attribution of $\mathrm{NO}_{\mathrm{x}}$ and other emissions during combustion. According to Zah et al. (2007), biofuels are beneficial in terms of GHG reduction but occasionally result in greater impacts on other environmental indicators during their production. The environmental impacts can be decreased by implementing appropriate practices, which will presumably offer possibilities to further optimize several production paths.

In relation to the produced heat, wood-based fuels contribute less to the GWP than natural gas (53\% decrease on average) when excluding biogenic carbon emissions but contribute more to acidification and eutrophication (on average, $57 \%$ and $44 \%$ increase). Including biogenic carbon reduces the calculated climate benefit since the total emissions end up being 4-7\% over those of natural gas use. In comparison, Puettmann and Lippke (2012) report that the greatest reduction in the GWP (66 \%) results from the increased use of forest residuals for heat energy, which is slightly higher than our findings without biogenic carbon emissions. Based on our study, the impacts on the AP and the EP of wood-based fuels are higher than the impact of natural gas due to $\mathrm{SO}_{2}$ and $\mathrm{NO}_{\mathrm{x}}$ emissions from wood combustion. According to Cherubini and Ulgiati (2010), biofuels often have a higher EP than a conventional fossil fuel life cycle. When electricity displacement is included, emissions are reduced. In our study, the emission factors of natural gas heat and grid mix electricity are approximately the same, and the energy production of the Saimaanharju CHP plant emits very little GHG. The selected emission values for grid electricity affect the results.

The normalized results in Figure 7 indicate that relatively most significant effect is the reduced GWP associated with wood-based fuel production. In the case of the normalized acidification impact, the district's heat from natural gas has lower values. All resources have relatively low Havukainen, J., Nguyen, M.T., Väisänen, S., Horttanainen, M. 2018. Life cycle assessment of small-scale combined heat and power plant: environmental impacts of different forest biofuels and replacing district heat produced from natural gas. Journal of Cleaner Production 172C, 837-846. 
normalized eutrophication impacts. It becomes apparent that focusing on different impact categories produces different conclusions and recommendations on the environmental impacts of using forest biomass for energy generation. LCA is suitable method to investigate the environmental impacts of wood biomass energy production and comparing it with fossil fuel based energy production. It is also advisable to show effect of the biogenic on biomass LCA results.

\section{Conclusions}

Environmental impacts - including the GWP, the EP, and the AP of the small-scale CHP plant utilizing different wood-based fuels and replacing the district's heat produced from natural gas with heat from the CHP plant - were calculated. Obtaining fuels (including the related transport, heat, electricity, comminution, hauling, and cutting) generates the majority of the GWP (82-92 $\%$ ) of the small-scale CHP plant. Combustion is responsible for the main percentages of the emissions causing the AP (72-94\%) and the EP (77-95\%). The calculated environmental impacts of utilizing forest biomass in the small-scale CHP plant in relation to produced energy are 2.2-5.1 $\mathrm{gCO}_{\text {,eq. }} / \mathrm{MJ}_{\text {energy, }} 133-175 \mathrm{mgSO}_{\text {,eq. }} / \mathrm{MJ}_{\text {energy, }}$ and 18-22 $\mathrm{mg}$ PO34-eq. $_{\text {}} \mathrm{MJ}_{\text {energy. Pellet }}$ production requires a large amount of electricity and heat and thus creates a higher impact than WCs. Additionally, when $43 \%$ of the district's heat from natural gas is replaced with heat from the small-scale CHP plant and electricity displacement is accounted for, the annual GWP is reduced by $51 \%-53 \%$, whereas the AP is increased by $47 \%-88 \%$, and EP is increased by 37 $\%-61 \%$. The results indicate that by using forest biomass instead of natural gas in energy production, the global climate impacts (GWP) are reduced when excluding biogenic carbon emissions, while the local effects are higher (AP and EP). Including biogenic carbon reduces the calculated climate benefit since the total emissions end up being 4-7\% over those of natural gas use. The potential benefits need to be weighed against the possible drawbacks.

\section{Acknowledgements}

The research was conducted in the Distributed Energy System (DESY) program funded by industrial and research partners and managed by CLIC, the solution architect for global bioenergy and cleantech opportunities.

\section{References}

Alakangas, E., 2000. Properties of fuels used in Finland (in Finnish), VTT Technology 258. VTT Technical Research Centre of Finland Ltd. Espoo.

Arvidsson, R., Fransson, K., Fröling, M., Svanström, M., Molander, S., 2012. How do we know the energy use when producing biomaterials or biofuels?, in: ECO-TECH 2012. 26-28 November. Kalmar, Sweden.

Asikainen, A., Ilvesniemi, H., Sievänen, R., Vapaavuori, E., Muhonen, T., (edit.), 2012. Bioenergy, climate change and Finland's forests (in Finnish), Finnish Forest industry 240. Vantaa.

Berg, S., Lindholm, E.-L., 2005. Energy use and environmental impacts of forest operations in Sweden. J. Clean. Prod. 13, 33-42. doi:10.1016/j.jclepro.2003.09.015

Berg, S., Schweier, J., Brüchert, F., Lindner, M., Valinger, E., 2014. Economic, environmental Havukainen, J., Nguyen, M.T., Väisänen, S., Horttanainen, M. 2018. Life cycle assessment of small-scale combined heat and power plant: environmental impacts of different forest biofuels and replacing district heat produced from natural gas. Journal of Cleaner Production 172C, 837-846. 
and social impact of alternative forest management in Baden-Württemberg (Germany) and Västerbotten (Sweden). Scand. J. For. Res. 29, 485-498.

doi: 10.1080/02827581.2014.927913

Bridgewater, A. V., 2004. Biomass fast pyrolysis. Therm. Sci. 8, 21-50.

Brofeldt, T., 2013. Phone conversation with Tapio Brofedlt, CEO of Biowin Ltd 2.5.2013.

Cambria, D., Pierangeli, D., 2011. A life cycle assessment case study for walnut tree (Juglans regia L.) seedlings production. Int. J. Life Cycle Assess. 16, 859-868. doi:10.1007/s11367011-0323-5

Caserini, S., Livio, S., Giugliano, M., Grosso, M., Rigamonti, L., 2010. LCA of domestic and centralized biomass combustion: The case of Lombardy (Italy). Biomass and Bioenergy 34, 474-482. doi:10.1016/j.biombioe.2009.12.011

Chen, S., 2009. Life Cycle Assessment of Wood Pellet, Master of science thesis. Chalmers University of Technology. Göteborg.

Cherubini, F., Huijbregts, M., Kindermann, G., Van Zelm, R., Van Der Velde, M., Stadler, K., Strømman, A.H., 2016. Global spatially explicit CO2 emission metrics for forest bioenergy. Sci. Rep. 6, 20186. doi:10.1038/srep20186

Cherubini, F., Strømman, A.H., 2011. Life cycle assessment of bioenergy systems: state of the art and future challenges. Bioresour. Technol. 102, 437-51. doi:10.1016/j.biortech.2010.08.010

Cherubini, F., Ulgiati, S., 2010. Crop residues as raw materials for biorefinery systems - A LCA case study. Appl. Energy 87, 47-57. doi:10.1016/j.apenergy.2009.08.024

CML - Department of Industrial Ecology, 2016. CML-IA Characterisation Factors [WWW Document]. URL https://www.universiteitleiden.nl/en/research/researchoutput/science/cml-ia-characterisation-factors (accessed 10.12.16).

Ecoinvent Centre, 2010. Ecoinvent Database v2. EcoInvent Database v2 Swiss Centre for Life Cycle Inventories.

Eriksson, O., Finnveden, G., Ekvall, T., Björklund, A., 2007. Life cycle assessment of fuels for district heating: A comparison of waste incineration, biomass- and natural gas combustion. Energy Policy 35, 1346-1362. doi:10.1016/j.enpol.2006.04.005

European Commission, 1997. Communication from the commission: energy for the future: renewable energy sources - white paper for a community strategy and action plan, COM 97, 599, Final of November 26, 1997, Brussels.

European Union, 2009. Directive 2009/28/EC of the European Parliament and the Council of 23 April 2009 on the promotion of the use of energy from renewable sources and amending and subsequently repealing Directives 2001/77/EC and 2003/30/EC (23 April 2009).

González-García, S., Berg, S., Feijoo, G., Moreira, M.T., 2009. Environmental impacts of forest production and supply of pulpwood: Spanish and Swedish case studies. Int. J. Life Cycle Assess. 14, 340-353. doi:10.1007/s11367-009-0089-1

Havukainen, J., Nguyen, M.T., Väisänen, S., Horttanainen, M. 2018. Life cycle assessment of small-scale combined heat and power plant: environmental impacts of different forest biofuels and replacing district heat produced from natural gas. Journal of Cleaner Production 172C, 837-846. 
Guinée, J.B., Gorrée, M., Heijungs, R., Huppes, G., Kleijn, R., Koning, A., Oers, L., Wegener Sleeswijk, A., Suh, S., Udo de Haes, H.A., Bruijn, H., Duin, R., Huijbregts, M.A.J., 2002. Handbook on life cycle assessment. Operational guide to the ISO standards. I: LCA in perspective. IIa: Guide. IIb: Operational annex. III: Scientific background. Kluwer Academic Publishers, Dordrecht.

Hagberg, L., Särnholm, E., Gode, J., Ekvall, T., Rydberg, T., 2009. LCA calculations on Swedish wood pellet production chains, IVL Report B1873. Swedish Environmental Research Institute. Stockholm.

Hammond, G.P., 2004. Engineering sustainability: thermodynamics, energy systems, and the environment. Int. J. Energy Res. 28, 613-639. doi:10.1002/er.988

Heikkilä, J., Laitila, J., Tanttu, V., Lindblad, J., Asikainen, A., Pasanen, K., Korhonen, K.T., 2005. Harvesting alternatives and cost factors of delimbed energy wood (in Finnish), Working papers 10. Finnish Forest Research Institute. Helsinki.

Ishikawa, S., Hoshiba, S., Hinata, T., Hishinuma, T., Morita, S., 2006. Evaluation of a biogas plant from life cycle assessment (LCA). Int. Congr. Ser. 1293, 230-233. doi:10.1016/j.ics.2006.02.008

ISO 14040, 2006. Environmental management. Life cycle assessment. Principles and framework.

ISO 14044, 2006. Environmental management — Life cycle assessment — Requirements and guidelines.

Juhl, L.F., 2013. Application manager, Skamol E-mail 9.8.2013.

Jäppinen, E., Korpinen, O.-J., Laitila, J., Ranta, T., 2014. Greenhouse gas emissions of forest bioenergy supply and utilization in Finland. Renew. Sustain. Energy Rev. 29, 369-382. doi:10.1016/j.rser.2013.08.101

Karhunen, M., Koskelainen, L., 2013. Presentation of Ekogen Company. Ekogen Ltd. Lappeenranta.

Karjalainen, H., 2015. Modelling small-scale CHP facility utilizing wood based biomass and micro turbine technology as a part of local district heat model (in Finnish). University of Jyväskylä.

Karjalainen, T., Asikainen, A., 1996. Greenhouse gas emissions from the use of primary energy in forest operations and long-distance transportation of timber in Finland. Forestry 69, 215228. doi:10.1093/forestry/69.3.215

Karttunen, K., Föhr, J., Ranta, T., 2010. Energy wood from South-Savo (in Finnish), Research report 7. Lappeenranta University of Technology.

Kimming, M., Sundberg, C., Nordberg, Å., Baky, A., Bernesson, S., Norén, O., Hansson, P.-A., 2011. Biomass from agriculture in small-scale combined heat and power plants $-\mathrm{A}$ comparative life cycle assessment. Biomass and Bioenergy 35, 1572-1581. doi:10.1016/j.biombioe.2010.12.027

Koskelainen, L., 2012. EKOGEN small-scale CHP plant. Lasse Koskelainen, technology

Havukainen, J., Nguyen, M.T., Väisänen, S., Horttanainen, M. 2018. Life cycle assessment of small-scale combined heat and power plant: environmental impacts of different forest biofuels and replacing district heat produced from natural gas. Journal of Cleaner Production 172C, 837-846. 
manager. Ekogen Ltd. Lappeenranta.

Kärhä, K., Hautala, A., Mutikainen, A., 2011. Utilization of Jenz HEM 581 DQ in road side comminution of forest residue and small wood (in Finnish). Metsäteho Ltd. Vantaa.

Laitila, J., Leinonen, A., Flyktman, M., Virkkunen, M., Asikainen, A., 2010. Challenges and development needs of wood chip procurement and supply logistics (in Finnish), VTT Research Notes 2564. VTT Technical Research Centre of Finland Ltd. Espoo.

Lectura, 2013. Timberjack 1270 B 1996 - 2001 specifications, technical data Model 1996-2001 [WWW Document]. URL https://www.lectura-specs.com/en/model/municipaltechnology/harvesters-timberjack/1270-b-1004015 (accessed 9.10.13).

Leino, M., Uusitalo, V., Grönman, A., Nerg, J., Horttanainen, M., Soukka, R., Pyrhönen, J., 2016. Economics and greenhouse gas balance of distributed electricity production at sawmills using hermetic turbogenerator 88, 102-111. doi:10.1016/j.renene.2015.11.029

Lipasto, 2012. LIPASTO - a calculation system for traffic exhaust emissions and energy consumption in Finland. VTT Technical Research Centre of Finland Ltd. Espoo.

Neuvonen, J., 2014. Technical manager Taipalsaari Municipality Technical services Phone conversation 8.1.2014.

Paroc Group, 2013. Paroc EPD MDP Environmental Product Declaration according EN 15804.

Pehnt, M., 2008. Environmental impacts of distributed energy systems-The case of micro cogeneration. Environ. Sci. Policy 11, 25-37. doi:10.1016/j.envsci.2007.07.001

Puettmann, M.E., Lippke, B., 2013. Using Life-Cycle Assessments to Demonstrate the Impact of Using Wood Waste as a Renewable Fuel in Urban Settings for District Heating. For. Prod. J. 63, 24-27. doi:10.13073/FPJ-D-13-00012

Puettmann, M.E., Lippke, B., 2012. Woody Biomass Substitution for Thermal Energy at Softwood Lumber Mills in the US Inland Northwest*. For. Prod. J. 62, 273-279. doi:10.13073/FPJ-D-12-00023.1

Raiko, R., Saastamoinen, J., Hupa, M., Kurki-Suonio, I., 2002. Firing and combustion (in Finnish), 2nd ed, ISBN 951-666-604-3. International Flame Research Foundation - Finnish Flame Research Committee.

Salomón, M., Savola, T., Martin, A., Fogelholm, C.-J., Fransson, T., 2011. Small-scale biomass CHP plants in Sweden and Finland. Renew. Sustain. Energy Rev. 15, 4451-4465. doi:10.1016/j.rser.2011.07.106

Sandilands, J., Kellenberger, D., Nicholas, I., Nielsen, P., 2009. Life cycle assessment of wood pellets and bioethanol from wood residues and willow. New Zeal. J. For. 53, 25-33.

Schleisner, L., 2000. Life cycle assessment of a wind farm and related externalities. Renew. Energy 20, 279-288. doi:10.1016/S0960-1481(99)00123-8

Sherwani, A.F., Usmani, J.A., 2010. Life cycle assessment of solar PV based electricity generation systems: A review. Renew. Sustain. Energy Rev. 14, 540-544.

Havukainen, J., Nguyen, M.T., Väisänen, S., Horttanainen, M. 2018. Life cycle assessment of small-scale combined heat and power plant: environmental impacts of different forest biofuels and replacing district heat produced from natural gas. Journal of Cleaner Production 172C, 837-846. 
doi:10.1016/j.rser.2009.08.003

Sipilä, K., Rämä, M., Pursiheimo, E., Sokka, L., Löf, A.N., Konttinen, J., Rodriguez, M., Ruggiero, S., Maunuksela, J., Hietaranta, M., Karjalainen, H., Valta, J., Kalema, T., Hilpinen, J., Nyrhinen, J., Rintamäki, J., Viot, M., Horttanainen, M., Väisänen, S., Havukainen, J., Hiltunen, E., Koivisto, R., Martinkauppi, B., Rikkonen, P., Varho, V., Rasi, S., Sinkko, T., Koistinen, L., 2015. Distributed Energy Systems - DESY, Technology 224. VTT Technical Research Centre of Finland Ltd. Espoo.

Soimakallio, S., 2013. Electricity production by fuels in Finland (unpublished research data, in Finnish). VTT Technical Research Centre of Finland Ltd. Espoo.

Statistics Finland, 2012. Average distance and fill rate of domestic road freight transport in year 2012 (in Finnish).

Tahvanainen, T., Anttila, P., 2011. Supply chain cost analysis of long-distance transportation of energy wood in Finland. Biomass and Bioenergy 35, 3360-3375.

doi:10.1016/j.biombioe.2010.11.014

Thinkstep, 2015. Gabi 6 Software-System and database for Life Cycle Engineering. Copyright, TM. Stuttgart, Echterdingen.

Uusitalo, V., Havukainen, J., Kapustina, V., Soukka, R., Horttanainen, M., 2014. Greenhouse gas emissions of biomethane for transport: Uncertainties and allocation methods. Energy and Fuels 28. doi:10.1021/ef4021685

Valente, C., Hillring, B.G., Solberg, B., 2011. Bioenergy from mountain forest: a life cycle assessment of the Norwegian woody biomass supply chain. Scand. J. For. Res. 26, 429-436. doi: 10.1080/02827581.2011.570783

Vesterinen, R., Paakkinen, K., Pyykkönen, M., Virkki, J., 1985. Emissions of district heating plants utilizing domestic fuels (in Finnish). VTT Technical Research Centre of Finland Ltd. Espoo.

Väisänen, S., Mikkilä, M., Havukainen, J., Sokka, L., Luoranen, M., Horttanainen, M., 2016. Using a multi-method approach for decision-making about a sustainable local distributed energy system: A case study from Finland. J. Clean. Prod. 137, 1330-1338. doi:10.1016/j.jclepro.2016.07.173

Wihersaari, M., 2005. Greenhouse gas emissions from final harvest fuel chip production in Finland. Biomass and Bioenergy 28, 435-443. doi:10.1016/j.biombioe.2004.11.007

Wihersaari, M., Palosuo, T., 2000. Wood energy and greenhouse gases. Part 1: Greenhouse gas emissions of wood chip supply chains from final felling (in Finnish)., VTT Energy Reports 8. VTT Technical Research Centre of Finland Ltd. Espoo.

Winter, F., Wartha, C., Hofbauer, H., 1999. NO and N2O formation during the combustion of wood, straw, malt waste and peat. Bioresour. Technol. 70, 39-49. doi:10.1016/S09608524(99)00019-X

Zah, R., Böni, H., Gauch, M., Hischier, R., Lehmann, M., Wäger, P., 2007. Life cycle assessment of energy products: Environmental impact assessment of biofuels. St. Gallen.

Havukainen, J., Nguyen, M.T., Väisänen, S., Horttanainen, M. 2018. Life cycle assessment of small-scale combined heat and power plant: environmental impacts of different forest biofuels and replacing district heat produced from natural gas. Journal of Cleaner Production 172C, 837-846. 
Zhang, F., Johnson, D.M., Wang, J., 2015. Life-cycle energy and GHG emissions of forest biomass harvest and transport for biofuel production in Michigan. Energies 8, 3258-3271. doi: $10.3390 /$ en 8043258

Østergaard, P.A., 2009. Reviewing optimisation criteria for energy systems analyses of renewable energy integration. Energy 34, 1236-1245. doi:10.1016/j.energy.2009.05.004 